\title{
The Midwife: A Narrative, Feminist Metaphor for Pastoral and Self-Care during Covid-19
}

\section{Nicole Dickson}

\section{SHORT BIO}

Nicole Dickson (MTh) is a narrative and pastoral therapist in private practice. She also heads The Institute for Creative Conversation, a non-profit organisation in Kempton Park, where she teaches narrative ideas and practices.

INSTITUTIONAL AFFILIATION

The Institute for Creative Conversation, Kempton Park; nicky@i4cc.co.za

ORCID

https://orcid.org/0000-0003-4795-3936

ABSTRACT
$\begin{aligned} & \text { This article explores the metaphor of midwife as a statement of position for } \\ & \text { supporting pastoral and self-care during Covid-19 times. It weaves collabora- } \\ & \text { tive threads of narrative therapy, feminism, and pastoral theology to explore } \\ & \text { meaning-making, the importance of stories, metaphors, and "voice" using the } \\ & \text { familiar language of pregnancy, namely "expectancy," "labour pains," and } \\ & \text { "birth." It seeks to offer a compassionate space for bearing witness to the } \\ & \text { effects of the pandemic on therapists and the people we encounter. }\end{aligned}$

KEYWORDS

Narrative therapy; feminism; pastoral; metaphor; liminal space

Allowing our wounds to become the womb where new life is conceived (Julian of Norwich).

\section{Introduction}

I have been a witness to people's stories for more than twenty years now. You see, as a pastoral narrative therapist, I am in the "business" of listening to stories, gathering stories, and bearing witness to the birth of new stories. It is the telling of stories that lies at the heart of all human experiences and which forms part of the fabric of pastoral work. Dr. Roberta Bondi, Professor Emerita at Candler School of Theology, Emory University, suggests that pastoral work is about the "messy particularity of everyday lives, examined with excruciating care and brought into conversation with the great doctrines of the Christian faith."1

This article draws on the values and ideas of narrative therapy, feminism, and pastoral theology. I will now offer some threads of these theories as they inform my practice, the community I am a part of, and myself as woman.

1 Roberta C. Bondi, Memories of God: Theological Reflections on a Life (Nashville: Abingdon Press, 1995), 17. 


\section{Why Narrative Therapy?}

I love stories and tales from childhood and the memories which books hold for me. I loved the bedtime stories read to me by my mother and my grandmother and I loved the stories of family history and memories shared by them of a time past. Their stories of "when I was young..." filled much of the knowledge and imagination upon which my early childhood was formed. It is therefore no surprise that I have been inspired by the narrative assumption that all life is constituted of stories and socially accepted discourse. According to Alan Parry and Robert Doan, "we dream in narrative, daydream in narrative, remember, anticipate, hope... hate and love by narrative."

\section{Why Feminism?}

As a woman, I witness how gender discourses inform the dominant patriarchal society which plays an ongoing part in silencing and minimising our voices and wellbeing. Feminist theory shares some common ideas with narrative therapy. Christie Neuger writes that feminism requires a "commitment to the belief that each individual life must be understood in the context of the power arrangements and rules of the dominant culture" 3 and that the construction of theory and practice must also listen carefully to each individual, marginalised voice. Carol Christ believes that "[w]omen's stories have not been heard. And without stories there is no articulation of experience... If women's stories are not told, the depth of women's souls will not be known." ${ }^{4}$ Feminist ideas of finding "voice," the importance of relationality in which to do this, and the emphasis on the community are briefly discussed next.

\section{Finding Voice}

"Hearing another into speech" is a term familiar in feminist writings. Marge Piercy writes, "She must learn again to speak. Starting with I. Starting with we. Starting as the infant does, with her own true hunger, and pleasure, and rage." ${ }^{5}$ When a woman is denied the opportunity to name and interpret her experiences, it is not surprising that one way we describe this, is through "loss of voice."

2 Thomas A. Parry and Robert E. Doan, Story Re-Visions: Narrative Therapy in the Postmodern World (New York: Guilford, 1994), 211.

3 Christie C. Neuger, Counseling Women: A Narrative, Pastoral Approach (Minneapolis: Augsberg Publishing House, 2001), 3.

4 Carol Christ, Diving Deep and Surfacing (Boston: Beacon Press, 1980), 1.

5 Marge Piercy, "Unlearning to not speak," in Circles on the Water, ed. Marge Piercy, (New York: Knopf, 1982), 97. 
Women's stories throughout history have strong elements of suppression, silence, and unworthiness. Miriam Greenspan writes:

The simple process of women sitting and listening to each other's stories respectfully and with an ear to the shared strengths as well as the shared ordeals had some very powerful therapeutic effects. Our relationship to everything - our bodies, our work, our sexuality, the men and women and children in our lives - emerged in a thoroughly new light. Together we saw that the old terms used to describe politics, relationships, sexuality, power and language itself were an outgrowth of male experience and had to be reinvented from our own point of view as women. For many of us, the overwhelming sense was of seeing the world through our own eyes for the very first time. ${ }^{6}$

Feminist theory has played a large role in questioning assumptions of gender and power relations, while the issue of language and voice has long been a hallmark of the feminist movement.

\section{Relationality}

This article also takes cognisance of Christie Neuger's suggestion that women have a unique tendency towards, and skills at building and maintaining relationships which can be seen as morally valuable and familially necessary. ${ }^{7}$ Whilst lockdown and social distancing has somewhat limited conventional expressions of relationships, the care and nurture of relationships remains important for reclaiming the value of women's lives and culturally given roles.

\section{The Importance of a Community}

Feminist literature suggests that it is important for women to belong to groups that help them to resist and reshape destructive personal and cultural narratives. Without the support and challenge of healing communities, re-authored, alternative narratives are often too fragile and too "thin" to be sustained when a woman takes them back into the context of patriarchal discourse, culture, and often, family. Communities and groups that work to hear and elaborate the new and alternative narratives help the woman to make this new narrative a viable part of her

6 Miriam Greenspan, A New approach to Women and Therapy (New York: McGraw-Hill Education, 1983), 233.

7 Neuger, Counseling Women, 233. 
life story. Alongside the narrative voice, this article suggests that the community is the space in which women are most likely to continue to gather evidence to support an alternative story.

\section{Why Pastoral Theology?}

I write/work as a member of a Christian community whose "normative ways of being in the world" are shaped by the "images and metaphors" of biblical narrative accounts of God's presence in the world. ${ }^{8}$ Herbert Anderson and Edward Foley suggest that our "engagement with the Holy - similar to our engagement with virtually every aspect of life - is mediated through word and gesture, body and song, architecture, poetry and movement." 9 This resonates with my understanding of embodiment. In this way, pastoral theology can lift up the body as a site of resistance and hope. Susan Dunlap believes that the body can be seen as a starting point for spiritual growth. ${ }^{10}$ She writes that, through bodies there can be extraordinary communion with others. A healing touch can be a starting point for connection with others, and thus the arena for connection with God. Our bodies continually remind us of our mortality and our limits as physical beings. A deep appreciation of our fragility as creatures opens the awareness that each breath is by the grace of God. We are reminded that we are all equals in our vulnerability and the inevitability of death. Our bodies can also be sources of solidarity with the suffering. The body at risk is a profound point of connection with the powerless of the earth. This idea of embodiment resonates with the physical metaphors used in this article.

\section{The Significance of Stories}

Stories have the power to shape our reality in that it constructs and constitutes who we believe ourselves to be, what we see, feel, and do. The stories we live with grow out of conversations, brought about in relational, social, and cultural contexts. ${ }^{11}$ The point of the "story," according to Jim Duvall and Laura Béres, is "an invitation to the therapist to

8 Charles V. Gerkin, Widening the Horizons (Philadelphia: Westminster Press, 1986), 489.

9 Herbert Anderson and Edward Foley, Mighty Stories, Dangerous Rituals (San Francisco: Jossey-Bass, 2001), 38.

10 Susan J. Dunlap, "Discourse Theory and Pastoral Theology," in Feminist \& Womanist Pastoral Theology, eds. Bonnie J. Miller-Mclemore and Brita L. Gill-Austern (Nashville: Abingdon Press, 1999), 145.

11 Alice Morgan, What is Narrative Therapy? An Easy-to-read Introduction (Adelaide: Dulwich Centre Publications, 2000), 5-8. 
participate in and witness the unfolding of the story."12 The idea that we live multi-storied lives is a familiar one in narrative therapy. Through the teachings of Michael White and David Epston, Jill Freedman and Gene Combs, Alice Morgan and others, we use language such as the "single story," the "problem-saturated story," the "dominant story," the "alternative story," "re-storying," and "thickening preferred stories." "13 In context, stories help us to make meaning of the world around us, to connect our past to our present, and to serve as a guide for the future. An example might be the dominant system of patriarchy which has, through the ages, asserted a single narrative of marginalisation upon women. Over time, a dominant story of the "weaker sex" has been told about women. The stories of women such as Bishop Purity Malinga (the first female Presiding Bishop of the Methodist Church of Southern Africa) and Kamala Harris (first female Vice President of the USA) are re-storying the possibilities for women to be elected into positions of power, previously held by men.

This year, the year 2020, we have added Covid-19 (also called a pandemic) stories - stories of living in lockdown, of illness, of loss and grief, and of living in liminal spaces. For the first time since becoming a therapist, I am living and experiencing my own version of the same story as those that I encounter. This has made us co-creators in this global story and has deconstructed any notion of expert knowledge between therapist and client.

\section{Metaphorically Speaking}

Metaphors are used regularly in narrative conversations. According to Michael White (2007:31), they are generally borrowed from particular discourses that invoke specific understandings of life and identity. ${ }^{14}$ Metaphors can shape people's views of themselves and the view of the problem or story that they share. In narrative conversations, metaphors are used to create stories about reality. Melissa Griffith and James Griffith (1994:193) believe that a metaphor "contains within it implicit,

12 Jim Duvall and Laura Béres, Innovations in Narrative Therapy: Connecting Practice, Training and Research (New York: W.W. Norton, 2011), 52.

13 Michael White and David Epston, Narrative Means to Therapeutic Ends (New York: W.W. Norton, 1990); Morgan, What is Narrative Therapy?; Jill Freedman and Gene Combs, Narrative Therapy: The Social Construction of Preferred Realities (New York: W.W. Norton, 1996).

14 Michael White, Maps of Narrative Practice (New York: W.W. Norton, 2007), 31. 
unstated assumptions about what is real and what is not." 15 Metaphors can also be used to grow an understanding or deconstruction of social discourses that can wield power over the minds and bodies of people who live within it. Metaphors offer us an entrance into someone's experience (written or spoken) more vividly than mere statements of facts. Lisa Hinz suggests that metaphors and images become a "midwife" between experience and language. ${ }^{16}$

It is within this understanding that the metaphor of midwife has come alive for me as I live and work in these Covid-19 times. It formed as I sat wrestling and lamenting "outside the tomb" on Good Friday during lockdown. I wrote:

Cocooned in darkness,

Stillness,

The sound of a heartbeat

Flows the blood of the lamb -

Tainted by betrayal

And the weight of the world.

A place of waiting,

Of rest,

Of mourning a life that was.

A place of anticipation

And new creation...

The dawn of a new birth

- Resurrection Sunday (Nicole Dickson journal entry).

In the days that followed, I reflected on the words I had written. The image of the tomb became an image of a womb and I had an overwhelming sense of waiting for something to be born, not unlike waiting for Easter Sunday. This metaphor of a womb was helping me to name my own experience of living in what felt like a liminal space. As I have continued to listen, to witness, and to gather stories during this time, the midwife has also become a prominent image for the role that I play in conversation with others.

15 L. James Griffith and Melissa E. Griffith, The Body Speaks: Therapeutic Dialogues for Mind-body Problems (Nashville: Basic Books, 1994), 193.

16 Lisa D. Hinz, Drawing from Within: Using Art to Treat Eating Disorders (London: Jessica Kingsley, 2006), 12. 


\section{The Midwife}

The metaphor of a midwife embraces my position within my own story of this time in lockdown, yet also in the stories of those that I accompany in therapeutic spaces. Historian Laurel Ulrich shares a line from an eighteenth-century midwifery book, "There is a tender regard one woman bears to another, and a natural sympathy in those that have gone thru' the pangs of childbearing, which doubtless, occasion a compassion for those that labour under these circumstances." 17

Karen Hanson writes that midwives and pastors (I interpret this to include those of us working pastorally or in helping professions) have much in common. ${ }^{18}$ Both are in the "practice of tending births, the physical and the spiritual." I resonate with her suggestion that she attends to "people in travail, in any kind of tribulation or anguish, as God does the miraculous work of delivering new life in its myriad forms." She writes that we are in the business of "assisting God in birthing new life in people and in their relationships with self, others, and God."19

Some thoughts which are nurturing the conversations that I am having, both with myself, my loved ones, and others are discussed next, using the familiar language of pregnancy, namely "expectancy," "labour pains," and "birth."

\section{Expectancy}

There has been a pregnant pause during lockdown which sees me waiting for something "new" to be born - be it for life to give birth to a "new normal" or for "life after pandemic" to emerge. I imagine that the time spent in lockdown is like a time of living in a liminal space. The term "liminal" comes from the Latin term "limen" (threshold) - any point or place of entering or beginning. A liminal space is the time between the "what was" and the "next." It is a place of transition, a season of waiting, and not knowing. In the words of Nancy Levin, we are invited to "honor the space between no longer and not yet."20

17 Laurel T. Ulrich, A Midwife's Tale: The Life of Martha Ballard, Based on her Diary, 1785-1812 (New York: Vintage Books, 1990), 12.

18 Karen R. Hanson, "The Midwife," in Images of Pastoral Care: Classic Readings, ed. Robert C. Dykstra (St. Louis: Chalice Press, 2005), 200-8.

19 Hanson, "The Midwife," 200.

20 Nancy Levin, "Is it Time for a Graceful Exit?" https://nancylevin.com/is-it-time-for-agraceful-exit/. 
I acknowledge that I have surrendered a measure of control over many aspects of my life to Covid-19 and lockdown, and I am transparent about my personal relationship with anxiety. As a result, body, mind, and soul call on me for loving care. Philippians 4:6-7 ${ }^{21}$ encourages me: Don't fret or worry. Instead of worrying, pray. Let petitions and praises shape your worries into prayers, letting God know your concerns. Before you know it, a sense of God's wholeness, everything coming together for good, will come and settle you down. For me, this has meant finding a balance of rest, regular meals, movement, and prayer even when anxiety and Covid news have tried to hi-jack my days.

\section{Labour Pains}

The old midwife calmly sponged off sweat

She hummed a lullaby to soothe her pain. ${ }^{22}$

As a mental health professional, I have not been immune to the disruption brought about by this pandemic, and the metaphor of labour pains has helped me to find a name for these disruptions. I am grieving the loss of contact with both of my children who live away from home. I am grieving the disconnection from life sustaining relationships. I am grieving the lonely journey of death, experienced by dear ones. I wrestle with guilt as I again acknowledge both the economic and racial privilege that my white skin affords me at a time when so many in our country, South Africa, are homeless, constrained by poverty, and excluded by racism. I lament and rage against the injustice of gender-based violence, women and child abuse, and femicide, as the numbers continue to grow during this time of lockdown.

I am very aware that I am not labouring alone. Some of my labour companions during this time of groans, pain, and panic are the image I have of God, the awareness of breath, and the narrative practice of externalisation.

\section{My Image of God as a Labour Companion}

Fr. William A. Barry SJ, in his book A Friendship Like No Other, suggests that "the best analogy for the relationship God wants with us is

\footnotetext{
21 Taken from The Message (Eugene Peterson, The Message: The Bible in Contemporary Language [Colorado Springs: NavPress Publishing], 2002).

22 Annalise Brigham, "Bringing life to all," 2020, https://www.poetrysoup.com/poems poets/poems_by_poet.aspx?ID=9669.
} 
friendship. God desires humans into existence for the sake of friendship." 23 From this invitation, I suggest that how we image God determines how we relate to God. This means that the image of God that I have right now is significant. It explains how I see the world around me at any given time. If I see God as a condemning God, then I might see the pandemic as a way in which God is indeed punishing humankind. If I have a loving, nurturing image of God, I am more inclined to sense God's own lament and loss alongside mine, and this moves me into a relationship in which I lean on God. I chose the latter.

\section{The Awareness of Breath}

Women in the pangs of labour are encouraged to breathe to help manage and work through the pain of birthing. An important role of the midwife is to "breathe with" those who labour. Conscious breathing is known to help calm racing thoughts and the lack of control that tends to accompany anxiety. Breathing relieves tension mentally, physically, and emotionally. It provides mental clarity, calms down the nervous system and can boost emotional states. In the moments in which anxiety threatens to overwhelm me, I remind myself to breathe - to inhale, hold, exhale, and hold. This is called square breathing and is a technique used when taking slow, deep breaths, usually to the count of four. It can heighten performance and concentration while also being a powerful stress reliever. It slows my racing heart and restores even breathing. In fact, the term "breathe" has become a mantra that I consciously speak to myself.

\section{Externalising Practices}

Michael White first wrote about the practice of externalising conversations in $1984 .{ }^{24}$ It is probably one of the practices that most sets narrative practices apart from other models. He writes that many people seek therapy, believing that the problems in their lives are a "reflection of their own identity." 25 Externalisation characterises the way in which the problem speaks, the tactics of power it uses, and strategies employed by the problem in order to establish dominance. White writes that externalising has the effect of "reducing power" of the problem. Externalising conversations, therefore, assists people with giving "expression to a range of experiences of life that they previously had not had the

\footnotetext{
23 William A. Barry, A Friendship Like no Other (Chicago: Loyola University Press, 2008).

24 White, Maps of Narrative Practice, 23.

25 White, Maps of Narrative Practice, 10.
} 
opportunity to express". ${ }^{26}$ Alan Parry and Robert Doan suggest that the outcomes of the externalisation of problems include reducing the sense of failure that people have in response to not having solved the problem and unity against the problem. ${ }^{27}$

I am intrigued with what the narrative practice of externalisation offers to conversations and how it invites me and those that I encounter into a position of being "allies" in finding ways to stand against the destructive forces of Covid-19 and all that it has brought with it. Once problems are externalised (i.e., viewed as if they do not simply exist as an inherent aspect of a person), they can be put into storylines. For instance, it is possible for us as therapists to ask questions about how long the anxiety has been an influence in someone's life, when it came into their life, if there were factors that contributed to its presence, what the real effects of the anxiety are (on the person, their relationships, and others), when these effects have been the strongest and weakest, what sustains the depression and what acts as remedies in certain situations. These sorts of questions, and many others, begin to place the existence of the problem into a storyline. Personifying Covid has enabled me to "converse" with "it" and to let it know, in no uncertain terms, how I hate what it is robbing me of. I have also exposed how it tries to use anxiety to overwhelm me. These externalising practices offer me a position of agency over the pandemic and the anxiety which accompanies it.

\section{Birthing}

I would like to offer the ancient midwifery practice of "calling into life" here. Stories suggest that in times where birthing or labour was protracted, the midwife is believed to have asked the mother to name the child so that she could call the unborn child by name, and the baby would enter the world. I imagine that I too am calling into life a world without pandemic, a life after pandemic, a life lived through the lens of a "new normal," a life restored to wholeness.

Below, I am offering some thoughts on "birthing" that come to mind.

\section{The Birth of New Language}

We are constituted in language. Language provides the basis for all our thoughts and gives us a "system of categories for dividing up our

\footnotetext{
26 White, Maps of Narrative Practice, 28-9.

27 Parry and Doan, Story Re-Visions, 211.
} 
experience and giving it meaning" so that our "selves" become the products of language. ${ }^{28}$ Language produces and constructs our experiences of ourselves and each other.

As the world comes to grips with all that it means to be living in Covid-19 times, we face the challenge of figuring out how to talk about the impact that the virus is having on our everyday lives. The pandemic has led to the creation of new words and phrases which help us to make sense of the changes that have suddenly become part of our everyday lives. Think of terms and phrases such as "Covid fatigue," "Zoom burnout," "coronacoaster," "Covidiot," and "coronacation."

\section{Doing Hope}

The final moment of the pregnant pause is the moment of birth. I liken this to hope. I have found Kaethe Weingarten's work on hope very meaningful. She suggests that hope, as a verb, is also the act of "doing hope." ${ }^{29}$ She defines this as the responsibility of the community to do hope with those who are hopeless. For Weingarten there is a sense that caregivers co-create hopefulness with those we journey with. She uses the concept "reasonable hope" in a similar manner. ${ }^{30}$

Weingarten defines reasonable hope as something

[b]oth sensible and moderate, directing attention to what is within reach more than what may be desired but [is] unattainable. Reasonable hope's objective is the process of making sense of what exists now in the belief that this prepares us to meet what lies ahead. With reasonable hope, the present is filled with working not waiting; we scaffold ourselves to prepare for the future. ${ }^{31}$

Doing hope invites me to be a birthing companion to those I meet with, and it invites me to hold onto hope in my own life.

\footnotetext{
28 Vivien Burr, An Introduction to Social Constructionism (London: Routledge, 1995), 44.

29 Kaethe Weingarten, "Reasonable Hope: Construct, Clinical Applications and Supports,"

Family Process 49, no.1 (2010): 5-25.

30 Weingarten, "Reasonable Hope," 8.

31 Weingarten, "Reasonable Hope," 7.
} 


\section{Creativity}

I am inspired by creativity. People around the world are re-imagining ways of "being" during this time. Consider the online offerings such as retreats, concerts, virtual tours of museums, cooking classes, conferences, and workshops, to name but a few. The important rituals and ceremonies through which cultures acknowledge times of transition are also finding new expression these days with people celebrating marriage, graduation, rites of passage such as bar mitzvahs, christenings, and funerals through online platforms. I see each moment of creativity as a counter story, an act of resistance to Covid-19. In this way, creativity is about constructing stories and experiences of dignity and beauty, despite the presence of the pandemic.

I can think of a couple of ways in which I have constructed an alternative story to the one of pandemic. One experience of creativity has been to create a small section in a room at home for my spiritual practices to take place, despite not being able to attend church services. Another was the collaborated family creation at New Year of a time capsule about 2020 and all that we as a family missed, learnt, achieved, and celebrated.

\section{Wrapping Up}

In conclusion, I do not only hear the stories of others. I have my own story to tell too. As these stories intersect, they change, and I am changed too. When these stories and the truths of our faiths enter into conversation with one another, our longing for healing and wholeness, and our faith in God's promises of a mended world, touch our consciousness in new ways. ${ }^{32}$

In this moment I find myself wondering about you, the reader:

1. What are you waiting for to be born out of this time?

2. How are you living in expectancy?

3. What image of God do you carry?

4. What is it you are doing to keep hope alive?

32 Denise Ackerman and Riet Bons-Storm (eds.), Liberating Faith Practices: Feminist Practical Theologies in Context (Leuven: Peeters Publishers, 1998), 125. 
I end with a gift of words spoken through the poetry of Natalie Evans, ${ }^{33}$ birth doula and midwife, who writes:

\section{Birth Blessing}

Close your eyes and breathe deep

Breathe in peace, breathe out pain

Imagine your feet

Toes curling into dirt

Think of yourself as rooted

Think of your place in the earth

How did you come to be here?

Through generations of women named

A maternal lineage

That brought you to this place

Think of their birth stories

What you know, what you believe to be true

Realize that their births carry deep wisdom

Some may carry the memory of joy and transcendence

Each birth is a powerful experience

Each birth traces down to you.

Just as you pass this knowledge on to your baby

Understand that your birth is your own

It will be different from all others

Like the swirls in your thumb

Your birth will have a unique pattern

Unfolding with each contraction

Rising and falling like a newborn's chest

This birth belongs to you

This birth is an opening

This birth is the end and a beginning

May this blessing of birth come to you without fear

May this blessing of birth come to you with great

understanding

My this blessing of birth make your heart soar

May this blessing of birth bring shouts of delight to your lips

Blessings to you and your birth (Natalie Evans).

33 Natalie Evans, "The Birth Blessing," n.d. https://www.natalieannevans.com. 


\section{References}

Ackerman, Denise and Riet Bons-Storm (eds.). Liberating Faith

Practices: Feminist Practical Theologies in Context. Leuven:

Peeters Publishers, 1998.

Anderson, Herbert and Edward Foley. Mighty Stories, Dangerous

Rituals. San Francisco: Jossey-Bass, 2001.

Barry, William A. A Friendship like no Other. Chicago: Loyola University Press, 2008.

Bondi, Roberta C. Memories of God: Theological Reflections on a Life. Nashville: Abingdon Press, 1995.

Brigham, Annalise. a.k.a. Audrey Haick. "Bringing life to all." 2020. https://www.poetrysoup.com/poems_poets/poems_by_poet.aspx ?ID=9669 (Accessed 15 August 2020).

Burr, Vivien. An Introduction to Social Constructionism. London: Routledge, 1995.

Christ, Carol. Diving Deep and Surfacing. Boston: Beacon Press, 1980.

Dunlap, Susan J. "Discourse Theory and Pastoral Theology." In Feminist \& Womanist Pastoral Theology, edited by Bonnie J MillerMclemore and Brita L. Gill-Austern, 133-47. Nashville: Abingdon Press, 1999.

Duvall, Jim and Laura Béres. Innovations in Narrative Therapy: Connecting Practice, Training and Research. New York: W.W. Norton, 2011.

Evans, Natalie. "The Birth Blessing." n.d. https://www.natalieannevans.com (Accessed 12 August 2020).

Freedman, Jill and Gene Combs. Narrative Therapy: The Social Construction of Preferred Realities. New York: W.W. Norton, 1996. 
Gerkin, Charles V. Widening the Horizons. Philadelphia: Westminster Press, 1986.

Greenspan, Miriam. A New Approach to Women and Therapy. New York: McGraw-Hill Education, 1983.

Griffith, L. James and Melissa E. Griffith. The Body Speaks: Therapeutic Dialogues for Mind-body Problems. Nashville: Basic Books, 1994.

Hanson, Karen R. "The Midwife." In Images of Pastoral Care: Classic Readings, edited by Robert C. Dykstra, 200-8. St. Louis: Chalice Press, 2005.

Hinz, Liza D. Drawing from Within: Using Art to Treat Eating Disorders. London: Jessica Kingsley, 2006.

Levin, Nancy. "Is it Time for a Graceful Exit?" https://nancylevin.com/is-ittime-for-a-graceful-exit/ (Accessed 20 August 2020).

Morgan, Alice. What is Narrative Therapy? An Easy-to-read Introduction. Adelaide: Dulwich Centre Publications, 2000.

Neuger, Christie C. Counseling Women: A Narrative, Pastoral Approach. Minneapolis: Augsburg Publishing House, 2001.

Parry, Thomas A. and Robert E. Doan. Story Re-Visions: Narrative Therapy in the Postmodern World. New York: Guilford, 1994.

Peterson, Eugene. The Message: The Bible in Contemporary Language. Colorado Springs: NavPress Publishing, 2002.

Piercy, Marge. "Unlearning to not speak," in Circles on the Water, edited by Marge Piercy, 97. New York: Knopf, 1982.

Ulrich, Laurel T. A Midwife's Tale: The Life of Martha Ballard, Based on her Diary, 1785-1812. New York: Vintage Books, 1990.

Weingarten, Kaethe. "Reasonable Hope: Construct, Clinical Applications and Supports." Family Process 49, no.1 (2010): 5-25. 
The Midwife: A Narrative, Feminist Metaphor

White, Michael and David Epston. Narrative Means to Therapeutic Ends. New York: W.W. Norton, 1990.

White, Michael. Maps of Narrative Practice. New York: W.W. Norton, 2007. 